\title{
The Role of Civic and Ethical Education in the Development of Students' Behavior in TahtayKoraroWereda: The Case of Kelebet Elementary School
}

\author{
Mulalem Yohannes ${ }^{1,}$, , Fitsumbirhan Tewelde ${ }^{2}$, Fitsum Abrha ${ }^{3}$ \\ ${ }^{1}$ Civic and Ethical Education Department, Shire, Ethiopia \\ ${ }^{2}$ Ethiopian Biodiversity Institute, Mekelle, Ethiopia \\ ${ }^{3}$ Political Science and International Relations Civics Department, Aksum University, Aksum, Ethiopia
}

Email address:

mulalem2009b@gmail.com (M. Yohannes), fitsum2008b@gmail.com (F. Tewelde)

*Corresponding author

\section{To cite this article:}

Mulalem Yohannes, Fitsumbirhan Tewelde, Fitsum Abrha. The Role of Civic and Ethical Education in the Development of Students' Behavior in TahtayKoraroWereda: The Case of Kelebet Elementary School. International Journal of Sustainable Development Research. Vol. 3, No. 6, 2017, pp. 77-84. doi: 10.11648/j.ijsdr.20170306.13

Received: September 23, 2017; Accepted: October 26, 2017; Published: December 14, 2017

\begin{abstract}
The main purpose of this research was to explore the role of civic and ethical education in the Development of Students' behavior in TahtayKoraroWereda the case of kelebet elementary school, northern Ethiopia. To implement this purpose, case study method was explored. Data were gathered from the school principal, vice principal, teachers, education experts and parents. Considerable numbers of students were participated in focus group discussion. Classroom surveillance was also conducted so as to comprehend the scope to which civic and ethical education teachers and others stakeholder gave opportunity for ethical issues during their instruction qualitatively. Moreover, students' conduct inside and outside the classroom was also observed. The participants for the interview and focus group discussion were selected purposely based on their willingness, responsibility, and cooperation, competitiveness. The coordination of parents and school administration was poor. The perception of students' right and responsibility, influence of external environment and family's socio-economic background of the students found to be the great challenge for development of Students' behavior. On the basis of this result awareness creation and skill development training for teachers need to be given. Improving school-parent relationships, involving stakeholders like the media, well known elderly people for the teaching of good behavior have to be practiced in creating ethical school behaved environment and the surroundings.
\end{abstract}

Keywords: Civic and Ethical studies, Kelebet, TahtayKoraro

\section{Introduction}

The task of civic and ethical education is increasingly known as the best means of combating diverse societal problems. It is also widely certified as pre eminent in promotion fundamental behaviors and skills of citizens essential for the well-being of societies. Nonetheless, many societies these days remained beset with numerous societal challenges, such as corruption, worsening of ethical behaviors, lack of moral qualities, lack of good governance, negligence for the common good and the like [1].

Hence, the formation of good citizenship, citizens who are well clued-up, mindful of the common good, committed to democratic values and principles autonomous respectful and participant has become the prime concern of education system of many countries. It can be added global warming and climate change and drug trafficking as the growing additional factors for the need of the subject matter presently [2]. Some of the major factors that initiate interest in the teaching of ethical education, according to [3], include: rapid changes in scientific output, increased cross cultural contacts, and weakening of national boundaries due to expansion of internet, satellite TV and other media.

In Ethiopia, the beginning of 1990 s was a influential period for civic \& ethical education. This was due to the 
major socio-political developments that took place in the country [4]. In May 1991, the pro- socialist military dictatorship was overthrown by armed political group Ethiopian People's Revolutionary Democratic Front (EPRDF). Mean while, this political party, established a transitional government under the guiding principle of the transitional period the charter. This charter, according to many observers, was unique in the country's political history for its stipulation of numerous democratic ideas. It was in line with charter that the education and training policy (ETP) of the country was promulgated in 1994 [5]. The promulgation of this policy could be considered as a milestone for the renamed interest of civic and ethical education in Ethiopia. In the mean time, the institute for curriculum development \& research (ICDR), a government affair for curriculum development in Ethiopia proposed civic education to be included in curriculum of the country [2]. In constructing democracy and facilitating the development of the country the Transitional Government has introduced the new educational and training policy [2]. The goals of the educational policy appear too protect in democratic values, such as equality liberty, justice, truth and respect for human rights [6]. In order to realize /materialize the intended educational goals, the MOE has developed civic education as a separate school subject for all grade levels [7]. Civic education has got attention by the government because it plays key role to build democracy and enhance prosperity [8]. In a democratic society it is also planed at producing informed, competent and responsible citizens by equipping them with civic knowledge, civic skills and civic dispositions so that they can effectively participate in the political, social and economic affairs of their society [9]. There have been poor manner of talking, dressing, disrespect of elders, lack of discipline, etc. It is also common to experience in day to day activity of many people in our country concerning the unethical conduct of children and youth. Thus one can be aware that this issue needs further investigation. This study, therefore, proposed to investigate the ethical/moral behavior of elementary school of Kelebet and their understanding of rights and duties.

\section{Significance of the Study}

This research attempted to explore the condition of the ethical/moral conduct of Kelebet complete elementary school students and their awareness of duties and rights. So the Significance of the study is to:

1. Build awareness about the current status of students' ethical behavior and knowing of their rights and duties among educators and other concerned bodies.

2. Inform teachers, parents and the community that they should be coordinated to realize the goalof civic and ethical education.

3. Evaluate the students' ethical behavior.

Geographical Scope

Kelebet elementary School is one of the schools in TahtayKoraroWereda, North West zone of Tigray, Ethiopia. It was established in 1993. It is a government owned school. There were 5 building blocks consisting of 14 class rooms, library rooms, administration office laboratory room, and pedagogical center. There were two toilet blocks for males and females students separately and it has four rooms each, the school has definite sport field. Electricity, tap water and telephone services were not fulfilled to the school. There were 14 Classes each consisting of 40 to 50 students. The school was complete elementary school (grade 1-8) and it had two Shift systems. There were a total of 745 students (386 boys and 359 girls) and 21teachers (of which 12 male and 9 female).

The school had language and social, science and mathematics, grade 1-2 teachers and 3-4 grade teachers departments. Each department has its head. There are also many co-curriculum activities. For instance, Civic and Ethics club, mini media club, language club, anti-AIDS, Red Cross club, and sport club etc. Each club had coordinators and members from both teachers and students respectively.

The school had displayed its vision, mission, ethical principles, organization values, rules and regulation, rights and duties and student's teachers and other reflecting quality of education package.

Conceptual Scope

This study was intended to explore the role of civic and ethical education on behavioral development of students at Kelebet complete elementary school in TahtayKoraroWereda. This study focused only on those students who were currently attending their lesson at kelebet complete elementary school. Therefore, the researchers focused only on understanding the rights and responsibilities and moral development of students. This research also tried to evaluate students' behavior related to their relationship with their teachers other school bodies, and their dedication to their lesson. The study tried to investigate whether the students' behavior was ethical and act based on their rights and responsibility.

\section{Methodological Scope}

In this Study, qualitative research was used to study the problem at hand. Qualitative research is a means for exploring and understanding the meaning individuals or groups attribute to a social human problem. Qualitative method focuses on the depth of information rather than generalization the whole population. Qualitative methods produce a wealth of detailed information about a much smaller of people and case [10]. Owing to this latitude the researchers were selected this approach to investigate the ethical conduct of kelebet elementary School students. So, the main reason for selection of this method was that, help the researchers to investigate the impact of Civics and Ethical Education on students overall understanding of their rights, responsibilities and their moral development.

Limitation of the Study

As this study focuses on the study of the role of civic and ethical education curriculum on the development of student behavior, there was inappropriate time and resources. The researchers interviewed four parents who have close relationship to the school. Unfortunately, they have two of them for giving information. The other parents were not 
available for the interview because of their personal issue. And again Theresearchers wereobserved 4 classrooms. But they did not go beyond two classroom observations because of the time constraints.

\section{Research Methods and Design}

\subsection{Research Design}

There are different strategies of qualitative research. Among which case study is one way of study method. Case study is a strategy of inquiry in which the event, activity, process one or more individual as was studied by [11]. Qualitative case study is an intensive and holistic description of a program a person process of implementation [12]. In this study, the researcherswere chosen the case study design in order to generate detailed information about the character of students. This is because it would enable theresearchers to have an in depth insight of the problem at hand and thus the study was bounded to a single school.

\subsection{Data Sources and Sampling Procedure}

Purposive Sampling was employed in order to conduct this study. The researchers were purposefully selected Kelebet Elementary School in Tabia Mai timket of TahtaykoraroWereda Government School. They were selected this School because it is located at the center of the wereda and it is oldest school compared with the other in the kebele. Moreover, the researchers' personal experience with different schools during their work experience, the researchers were able to decide to study this situation further. The researchers were selected, school principal, vice principal, 8 teachers, 16 students, 2 education experts of the wereda administration bureau of Education and 4 parents to be the research participation. It was tried to be more inclusive in selecting teachers. The criteria for selection of teachers were their willingness and responsibility in the school. Students were selected form grade $5^{\text {th }}$ to $8^{\text {th }}, 4$ from each grade according to their academic performance and self expression. They were also selected based on the recommendation of the teacher due to their assertiveness and willingness in order to represent all students accordingly. Parents were selected among those parents listed the school and their part with the school in related to their Parent Teacher and Students Association (PTSA).

\subsection{Data Gathering Techniques}

For this study Interview, Observation, Focus Group Discussion (FGD) and document analysis techniques was used.

\subsection{Interview}

In qualitative research, Interview was a major instrument of data gathering [11]. It is used to collect live from the data the interview will used to conduct in face-to face encounter (between the researchers and the informant) and in a place where convenient for the interviewees. The interview was conduct in Tigrigna because of its Suitability to the study population, questions was constructed not as an end by themselves rather they developed in a manner under investigation. The vice principal, the teachers, the education experts and the parents were interviewed. The interview with these key informants was done intermittently at different times; while, the interview with experts was on pre -arranged program.

The interview was conducted in the form of gracious dialogue especially with teachers and principals. This friendly dialogue (conversation) supposed to enable the informants felt free, relaxed and confident.

\subsection{Observation}

Participant observation is a major means of data gathering instrument in case study. Participant observer should live close to the individuals $\mathrm{s} / \mathrm{he}$ is investigating trying to blend in and taking part in their daily activities [11]. For this study, the researchers were make classroom and outside classroom or field observation. The key points to observe inside the classroom was mainly related to the extent teachers give emphasis for ethical issues.

\subsection{Focus Group Discussions (FGD)}

Focus Group Discussions (FGD) was used to obtain information from the students. Sixteen Students were selected purposely from grade 5 to grade 8 , four students from each grade to represent each grade levels from different perspectives as much as possible. The researchers were prepared semi-structured questions for group discussion. The researchers were leading the discussion and strive to investigate the views and ideas of each discussant by probing them. The Focus Group Discussion focus on the conduct of the students, teachers effort to foster ethical conduct of the support of parent to the school and how did Civic and Ethical Education promote students' ethical conduct and allowing them to exercise their rights and responsibilities properly.

\subsection{Document Analysis}

In order to triangulate the data collected from different sources, the researchers were reviewed School attendance, and the rules, regulations of the school and the activities of club citizen and ethics of the school.

\subsection{Data Analysis}

According to [11] qualitative data analysis is conducted concurrently with gathering data, making interpretation and writing reports. The authors further added at case study involve a detailed description of the setting /individuals followed by analysis of the data for themes or issues. The data gathered by interviews was first transcribed.

The researchers attempted to read all the data bit by bit continuously till the meaning of those varieties of data collected by different techniques get. After a thorough reading of data the researchers attempted to develop 
categories or codes and reducing the voluminous data into manageable sets of themes. Using direct quotations and narrative descriptions each theme was analyzed. Therefore, $\mathrm{Ta}-\mathrm{Th}$ codes were used for teachers, $\mathrm{Pa}-\mathrm{Pb}$ for parents, the remaining participants was used without code names throughout the result of the study.

\section{Result}

\subsection{The Perception of Participants Toward CEE}

The researchers attempts to investigate whether participants' perception is in support of or against ethical education. One participant teacher (Non CEE teacher), Th, has the following to say: "The essentiality of character education for our children is crucial if we need to have children who are well mannered and disciplined. This type of education should be given equal emphasis as that of other academic learning”. Another Participant, Tg, a teacher, on his part reported: More than anything else our children should be cultivated in order to have good character. Unless the government gives suitable emphasis to this aspect of education, the end result will not be good whatever knowledgeable and skillful they are, if they do not have ethical conduct they will not be useful members of our society. Parents also thought their children to be good children. The government also needs to work hard through different mass media to address ethical issues. Similarly the education expert underlined the significance of ethical education by analyzing his own rational and the emphasis of the government. In order to produce good citizens who will be competent, responsible and honest, educating children/students to develop good conduct has no replacement. That is why the government has given owed awareness for ethical aspects of education.

\subsection{Rights and Responsibility}

The data obtained revealed that students in this school were not responsible for what they are expected to be. The teacher participants confirmed that their students are not good at shouldering responsibility. For instance Tf, who has served for long periods reported, I have worked as a teacher for about 8 years. For me the situation is changing from good quality to bad, the students today do not want to do anything for the school and for teachers. Tf, Added the new education system was visualized to talk our backwardness and poverty so as to facilitate our prosperity. From the lower level up to the higher level graduate, they are selfish, irresponsible, un helpful etc. when we come to our students, they werereally selfish. They always run to protect their rights without caring out their responsibility. They were very serious for pieces of their rights. But they are negligent for their responsibility.

My son asks me for breakfast or lunch as if he would go to school. After having his meal he leaves the home. He comes back when it was time to leave the school. By considering that he spent the time learning as his classmates, I welcome him imaginatively. I usually worry about his meal and wear. I worked day and night in order to allow my son successful in his learning. The son was cheating his mother while her expectation was the successful accomplishment of his learning. As explained by the principal the students damage many things. Heexplain that desks, doors are usually broken. They do not keep their class room clean as requred.

Here, we can imagine that with no doubt the physical presence of the students is nothing if their mind is not present at the same time. The day dreaming clearly shows they lose interest. TF, (teacher participant) also expressed her complain by describing what she usually encountered in the classroom. Her attempt to solve the problem by discussing with them could not bring any change. She expressed her frustration by saying "I can do nothing more than this, it is up to them". The Vice principal's idea strengthens what have been said by other teachers. "Teachers, usually come to my office and report the problem." The V/principals added that since the majority of them do not study during the exam time, they become active to cheat.

The researchers' observation of the classroom goes in line with what the majority of the teachers committed. While they were observing the instruction of the teachers, the researchers could see many students felt unmotivated, somewhere whispering, some were learning on their neighbors' body and some other day dreaming.

\subsection{Respect for People and Rules}

When we see our students, they are no more respectful to their teachers. They consider their teachers as their peers. They have no good manners when they approach their teacher. Another participant Td also reported; our students are no more respectful. They are selfish. They can offend you unless you are wise how to approach them. They do not bother whether their action affects your feeling or not, they have no patient to listen to you, they are only good loquacious.

P1 a parent participant also reflected the children's lack of respect even for their parents. This mother explained; I usually attempted to advise my son to study, to find good friends, and to help the family when he has spare time, but none of my effort becomes fruitful. He was not ready to listen and consider my help. He does not give any value for my advice now, I abandoned everything. The students today are difficult for parents.

\subsection{Commitment of Teachers to Cultivate Students Behavioral Development}

It was found that CEE teachers are also making effort to foster the character of students, although their effort is not as expected. The education expert explained the situation by saying "other subject teachers consider CEE teachers are the guardian of character development. Other subject teachers consider teaching their own subject matter as the only responsibility. This is problem for the school of course; we do not believe that they have no awareness about their full responsibility. Tg CEE teacher said: When we see the view of 
other subject teachers, they suspect that we are the members of the ruling party and they think we get special benefit. This wrong perception of teachers to the subject CEE was attributed for the failure of reaching the described objectives [8]. The data obtained from other subject teachers also seem to be congruent in the above participant.

Therefore, they must teach it. Even if it is my interest to teach ethics, how can I do it? My subject does not allow me. The very nature of the subject biology is not related to ethics. For e.g. If I raise one ethical issue in the classroom and deal with it, the students will observe us with support of the ruling party, they may consider it as wastage of time or they may regard me as a party member or conservative.

\subsection{Management of School Administrators and Students' Behavior}

Schools have their own rules and these rules are expected to be enforced firmly in the school. Kelebet complete elementary school like any other schools has its own rules and regulations. Some of the rules have been made at the top level (regional administration Bureau of education) and other rules are established by the school itself. As the expert said "schools have the right to make their own rules based on their school situation by the participation of the staffs, students, parents and other concerned bodies/stake holders". The school principal and vice principal explained that the rules which passed down from the regional administration and prepared at the school level are communicated to the students by the beginning of every academic year and also displayed to the students on the notice board. The researchers have also confirmed what the principal and vice principal said by his observation to the students. There are grounds rules in each class room, the rules and regulations, duties and responsibilities of teachers and students have been posted on the notice board as well as on the wall of the principals' office. These attempts, of course, should be appreciated.

However,

Nevertheless, the information obtained from interview, FGD and observation in directed that they are less functional. The teachers and the student participants confirmed that the school administration does not encourage and reward the club to be effective

Tc also reported I think that clubs are launched because we have to do this. Most of us know only the names of 3 or 4 clubs; others are heard when they are reported. But not seen what they were doing. The response of the expert seemed similar to what teachers and students argued. Even though all schools have formed different clubs, based on our evidence most of them are not effectively functioning.

\subsection{The Role of Parents and Community}

It is obvious that the involvement of parents and the community helps the school to be effective to attain the intended objectives of knowledge, skill or value. The participants of the study told to the researchers the involvement of parents and the community is insignificant for instance $\mathrm{Tb}$ said: "Parents are very distant from the school. They are not voluntary to come to the school and to communicate with teachers about their children some time when they are called the majority of them do not come accordingly".

They need the schools to do everything which is impossible. What is supporting is that they blame the school for not cultivating students but there is a sign of improvement. The teacher (Ta) and the vice principal both underlined the neglect of parents to be involved in their students learning.

The students' participant said "Many parents considered coming to the school as a waste of time. $\mathrm{Pb}$, a parent's participant reflected his examples and suggestion concerning his link with the school. It is my second time to come to school. I come on September when the school was opened. I came on that time because my daughter forced me to go because the school administration passed strong order for every student to take their parents. Only $25-35$ parents were present at that time the school demands us to frequently visit them but we are very busy on our daily activity issue. Accordingly, this school attempts to get the help of other individual. The information found from the vice principal and CEE teachers revealed that the school has good partnership with the police office, and wereda administration.

\subsection{Challenges to Development of Ethical Behavior}

Tc has commented children from the poor families may be exposed to bad behavior because of poor influence and lack of model at home. But some time the reverse happening like students from rich family are using drugs, alcohols etc, but the students from poor family are more of religious.

The idea of Tc tells us that parents today have become selfish. They are no more concerned for any child except their own. We, Ethiopians, have been known for their core social value. Let alone for our children we have been acknowledged for our hospitality for foreigners. One education expert explained the impact of family back ground as follows, It is clear that children of poor family back ground are exposed to various challenges. Moreover, the financial shortage pushes them to find other alternative. For this kind of students case should be given by the school and teachers unless teachers are committed to help these students they are easily exposed to different problems. The teachers expected to give especial counseling and guidance for them, encouraging them.

Of course, the support of the teacher is always needed for the healthy development of the students' behavior. However, these kinds of children need more attention than others.

\subsection{The Impact of External Environment on Student Behavioral Development}

The participant expressed their deep concern on the negative impact of the external environment on students' character development. According to them unless this situation is resolved, the effort of the school cannot be 
effective as expected.

For e.g. Td Said Our students are exposed to different challenges. In the classroom we teach them about good behavior, pro social behavior. However, in the real environment they have exposures to children, youngsters of adults who demonstrated bad behavior undesirable behavior. This is really unfortunate for our students and the next generation because our students are being losing their values and identities. The authors pointed out that today due to advancement of Information communication technology. The youth of the world are greatly affected by social ills; and this result in excessive materialism. Tg's idea also strength and what have been explained by her colleagues. I am very pessimist for the future of our students. We are not helping them. The government seems unconcerned for the grave challenge that faces us in the future. While our students are going to the worst way, nobody is committed to help them take the right way. We expect them to be good but we expose them to the ocean of life crisis. We adults are also not good models for them. Extending her discussion she argued, the government must be concerned for the problems of students and youth. The teaching-learning process cannot bring the required change unless the outside surrounding supports it.

\section{Discussion}

The participants were in support of the need for character education. Both gave due emphasize for the significance of ethical education. There is little doubt that the ideas above all depicted that ethical education should be the concern of every individual. It is implied that this aspect of education makes our students to develop the desired behavior. This investigation matches with many educators such as [13]. Therefore, it is possible to say that the participants of this study were in favor of ethical education. As can be seen from the above idea, students were strong enough to defend their rights and they do not compromise their rights. Nevertheless, it is also indicated that these students do not need to carry out their responsibility which is inseparable from their rights. One student participant said" the rights given to the students are very much exaggerated. The above statement imply that the students may not understand of their rights. In the first place they do not understand equality of human beings. In a democratic system every individual has equal rights. In spite of unclear understanding for rights, from the students view we can understand the rights given to student's cause's confusion to the students to carry out their responsibility. From the students' idea, it is implied that the students are aware of their rights on their own way.

The students' responsiveness can be also reflected by this commitment to protect the school properties from destruction. It is clear that the students have a right to utilize school properties but wisely. From the lists of the rights of the students it was stated that the students has a right to use school furniture and equipments.

The researchers were also able to judge that the teachers are bored of such mal practices because they welcome every behavior as it comes. The bench mark is zero drops out and zero detained rate" the students know that whether they attend the class or not, whether they study or not, etc. They were sure that they will not be either suspended or detained. Therefore, the researchers think, this may be one a major reasons for the failure of students to learn. From both participants' viewpoints, it seems that the students' rate to respect their teacher is poor. Students lack the values of considering others feelings. They are concentrating on their own feelings only. One can clearly see here that in such as a situation the students can lose a lot of advantages. Because of their poor approach to their students, teachers may not be interested and motivated to help their students.

The data obtained from Focus Group Discussion (FGD) revealed that teachers do not feel comfort when students boldly confront them to defend their rights. As Eden uttered, "I do not surrender for anybody. Opposite to the expectation of the teachers, the expert by reflecting his owns belief and the government. Assumption concluded that teachers complain because of the wrong expectation that teacher hold for students' behavior. Implicit to the expert's idea we can see that teachers do not want the students to be challenging to defend their right. From his interview the researchers was able to understand the experts reflected their idea on behalf of the government, not their own personal idea. The majority of their ideas were similar to the rhetoric uttered by government bodies at educational discourses. During his observation what the researchers observed inside and outside the class room did not agree with what the experts argued. Definitely, teachers are frustrated by the behavior of the students. The argument of the students can also imply that they have developed a rigid notion of defending ones, right. In this kind of situation it is not difficult to imagine that the students can abuse the teachers while they attempt to question any issue in order to defend their rights.

Based on the nature of the subject, all subjects may not have similar potential to affect moral development. For instance, values may be better fostered by social science or literature than some other subjects [14]. However, it does not mean that some subject should be neutral of moral education should be coordinated both horizontally (across academics in the same grade level) and vertically (across different grade levels). The data revealed that other subject teachers have no contribution for moral education.

Although this is particularly impossible, the teachers; deliberately effort to keep students develop moral understanding is very weak. Thus, without the involvement of teachers for moral development of students, the effort of CEE alone will not be effective [15]. Therefore, the absence of teacher (other subject) corporation for character development is one great challenge in spite of other efforts.

Having good rules cannot guarantee for fostering good behavior. On top of the school community needs to be model to demonstrate good behavior for the students.

Co-curricular activities are other tools which behaviors are shaped. Different curricular activities help learns develop good character as a result of real life experience. Because of 
their great contribution to the whole development of the learner, schools develop different co-curricular activities or clubs. As can be seen their clubs have direct relations to behaviors or ethical issues. The governments believes to cocurricular activities have key roles to promote students ethics. But the practice is for the teachers. The governments cannot go to school and participate in the actual. Of course, it is the responsibility of the government to develop programs, establish rules a follow up the practice. But weak at actual practice, probably this trend may be reflected in any function of the school. Not only parental involvement is needed but also the involvement of other people is also essential to effectively promote students ethical behavior.

It has been known that the traffic police teach the students about traffic rules and regulations, the police office teach about crime, violence, drugs, etc. The same lesson is given by the court men but almost the students did not change it in to practice. This effort of the school undoubtedly should be appreciated; however, the school cannot escape from critiques. Of course, it is very important for the students to know the rules and laws. It is better for the school to have partners with other individuals or groups such as professionals like health officers, psychologists, well respected persons, elders, etc.

When we see students who are misbehaved almost all of them either without parents or economically poor parents. The school vice Principal also suggested; Children from the poor families have a lot of burdens from their home. In the first place, these kinds of parents do not encourage their children. It is also implied that when children are not encouraged and modeled to develop good behavior, they are likely to be exposed for bad behavior.

To sum up, if children do not get good parental support in the home and in the school, their academic as well as ethical development can be influenced negatively. Especially, at early stage of starting adolescence children needs guidance, counseling and encouragement to direct their way because human beings learns ethical behavior or good conduct from the environment where he/she interacts [13]. Most importantly economic factors can greatly influence children's behavior. In one case, if there is financial shortage forced to search for another alternative to get money instead of giving attention to their education. This in turn can lead them to be exposed to such bad habits as their children are not yet mature to resist such challenges.

More than what they learn in the classroom the students are greatly influenced by the external event. The increasing of local drink houses (tela) and mobile videos affect the behavior of students greatly. However, they underestimate the negative impact of these phenomena on their behavior development. They suggested that if parents are strong enough to manage their children, the possible problems can be very minimal. It is not surprising to hear from students such idea that these new circumstances may not have immediate negative impact on their behavior. In one case, they assume that their behavior is not as bad as the society expects. Second, their awareness on the impact of the circumstance may be low. Teachers have also strongly recommended that unless good measure is taken to prevent this aggressive growth of social evils (local alcohol, video film, etc) the attempts of the school to foster good character of students cannot be realized. Generally speaking, the incompatible social environment (outside school environment) with the school is a big obstacle for the development of students' behavior as students because youth can be easily attracted by what they encounter.

\section{Conclusion}

Even though CEE has been give as a separate subject in elementary schools; the behavior of some students in Kelebet elementary school was found unethical.

The rules and regulations of the school were violated by the students. The students do not take care for school properties. They were not committed to their learning. Moreover, the norm of respect for teachers was almost ignored by the students. It was found that some students ignored the advice and order of teachers. Some teachers demand students to develop ethical behavior. They criticize the students for their bad behavior. However, except CEE teaches other subject teacher were not aware of their responsibility to promote the ethics of students it should be related to the students' real life experience. The involvement of parents in promoting their children's behavior was poor. Some parents were not responsible and closely work with the school so as to support the student's ethical conduct. Though the school has variety of extracurricular activities commitment of the school to enforce some of them seems weak. Most of the rules were violated by the students.

Students justify that it is the order of the day to prevent one's rights, to express idea and thought freely. Definitely in a democratic system individual rights and freedom are at the center of education and other walks of life.

However, defending rights cannot be at the expense of disrespecting the common goods i.e. the norms, traditions, rules and values of the society. Ignoring responsibility causes a great crisis. While we claim our rights we are also responsible for others. This means rights and responsibility are inspirable if we are citizens who respect the common values of people. It can be understood that some students were in a state of confusion to recognize individual rights and social standards. We are always living in the society and our life depends on the society. According to the assumption of teachers, the sense of individualism (commitment only to individual interest) that has become the dominant value for students today is mainly due to the government's commitment to give much emphasis for students' right without paying attention for their social responsibility.

Students in Kelebet elementary school were committed to their rights only but not as much for their duties and responsibilities. So, there is a gap what teachers and parents claim and what the students have developed. This may lead to generation gap of promoting our own values.

Advancing students ethical behavior can be realized when 
the school teachers, the principals, the parents and the local community are concerned and committed to work for ethical values. Absolutely or openly, the teachers transmit ethical massage to the students by his/her examples /models, selection of materials, his/her decision, the behavior that she/he demonstrates. It is therefore, necessary for all school teachers to be responsive of their roles to influence the students' moral behaviordevelopment.

\section{Acknowledgements}

The authors would like to express thanks to the education stakeholders (parent, teachers, students, principal and vice principal) of Kelebet complete elementary school and TahtayKorarowereda education office experts for their cordiality and kind response to inquiries on information about therole of civic and ethical education in the Development of Students' behavior.

\section{References}

[1] Sharma, Y. K. (2006). Sociological Philosophy of Education. New Delhi: Kanishka publishers.

[2] Akalewold Eshete (2005). Civic \& Ethical Education Curriculum Policy: Recent Government Interest \& Subsequent Development. IER. Flambeau - volume 13, Number 35.

[3] UNESCO (2003). Report of the Working Groupon the Teaching of Ethics. Paris, COMESTWade G. R (1997). Community ServiceLearning: A Guide to Including Service inthe Public School Curriculum. New York, State University, New York.

[4] Girma Alemayehu (2006). The Implementation ofGrade 8 Civic \& Ethical Education: TheCaseof Addis Ababa City Administration: unpublished MA thesis, AAU.

[5] Solomon Areaya (2008). Policy Formation, Curriculum Development \& Implementationin Ethiopia. Addis Ababa. The Book Center(AAU).
[6] Seyoum Tefera (1996). Attempts in Educational Reform in Ethiopia: A Top-down or aBottom-up Reform. The Ethiopian journal of Higher Education, Volume xvi, Number, 1-37

[7] MOE (2002). "Zegoch min esetochinyigenbu?" What values should citizens build? Amharicdocument- Addis Ababa, EMPDA.

[8] MOE 2006). A Discussion Paper on Civic \& Ethical Education for Teachers, Principals\&Supervisors (Amharic Document) AddisAbaba, EMPDA.

[9] Birhanu Jibril Gelaneh (2012). The Role of CivicsandEthical Education in the Development of Students' behavior: The Case of Kokebe Tsibiha Secondary and Preparatory school. AAU: MA thesis.

[10] Patton (1990). Qualitative Evaluation \&ResearchMethods. USA; Sage Publishers

[11] Cresswell, J. W. (2009). Research Design: Quantitative, Qualitative \& Mixed Methods Approach (third edition). USA, SAGEpublishers. Inc.

[12] Solomon Areaya (2004). Qualitative Research: Beyond a Number Game. IER Flambeau, AAU, Volume 11, Number 2(1-12).

[13] Dawit Lemma (2006). Perception of Teachers \&Students towards Civic \& Ethical Education\&itsPractice in Selected PreparatorySchools ofSouth West Shoa Zone, unpublished. AAU:MA thesis

[14] EyayuHailu (2007). The Inclusion of Ethiopian Common Social Values in Civic \& Ethical Education Curriculum \& Instruction in Secondary Schools of Adama. AAU: MAthesis.

[15] GhermaiAlemayehu (2003). The Rights of Child Education for Citizenship in Ethiopia. In the proceedings of the national conference on the situation of child rightseducation in Ethiopia.

[16] Annual plan k. s. (2015/16). Annual plan ofkelebet complete elementary school, unpublished data. 